\title{
Nitrogen Transfer from Four Nitrogen-Fixer Associations to Plants and Soils
}

\author{
Kathrin Rousk $\odot,{ }^{1,2 *}$ Pernille Laerkedal Sorensen, ${ }^{1}$ and Anders Michelsen ${ }^{1,2}$ \\ ${ }^{1}$ Department of Biology, Terrestrial Ecology Section, University of Copenhagen, Universitetsparken 15, 2100 Copenhagen, Denmark; \\ ${ }^{2}$ Center for Permafrost (CENPERM), University of Copenhagen, Oster Voldgade 10, 1350 Copenhagen, Denmark
}

\begin{abstract}
Nitrogen $(\mathrm{N})$ fixation is the main source of 'new' $\mathrm{N}$ for $\mathrm{N}$-limited ecosystems like subarctic and arctic tundra. This crucial ecosystem function is performed by a wide range of $\mathrm{N}_{2}$ fixer (diazotroph) associations that could differ fundamentally in their timing and amount of $\mathrm{N}$ release to the soil. To assess the importance of different associative $\mathrm{N}_{2}$ fixers for ecosystem $\mathrm{N}$ cycling, we tracked ${ }^{15} \mathrm{~N}-\mathrm{N}_{2}$ into four $\mathrm{N}_{2}$-fixer associations (with a legume, lichen, free-living, moss) and into soil, microbial biomass and non-diazotroph-associated plants 3 days and 5 weeks after in situ labelling. In addition, we tracked ${ }^{13} \mathrm{C}$ from ${ }^{13} \mathrm{CO}_{2}$ labelling to assess if $\mathrm{N}$ and $\mathrm{C}$ fixation are linked. Three days after labelling, half of the fixed ${ }^{15} \mathrm{~N}$ was recovered in the legume soils, indicating a fast release of fixed $\mathrm{N}_{2}$. Within 5 weeks, the free-living $\mathrm{N}_{2}$ fixers released twothirds of the fixed ${ }^{15} \mathrm{~N}$ into the soil, whereas the
\end{abstract}

lichen and moss retained the fixed ${ }^{15} \mathrm{~N}$. Carbon and $\mathrm{N}_{2}$ fixation were linked in the lichen shortly after labelling, in free-living $\mathrm{N}_{2}$ fixers 5 weeks after labelling, and in the moss at both sampling times. The four investigated $\mathrm{N}_{2}$-fixer associations released fixed $\mathrm{N}_{2}$ at different rates into the soil, and nondiazotroph-associated plants have no access to 'new' $\mathrm{N}$ within several weeks after $\mathrm{N}_{2}$ fixation. Although legumes and free-living $\mathrm{N}_{2}$ fixers are immediate sources of 'new' $\mathrm{N}$ for $\mathrm{N}$-limited tundra ecosystems, lichens and especially mosses, do not contribute to increase the $\mathrm{N}$ pool via $\mathrm{N}_{2}$ fixation in the short term.

Key words: cyanobacteria; diazotroph; legume; lichen; methanotroph; moss; stable isotopes; subarctic; symbiosis.
Received 30 July 2015; accepted 20 May 2016; published online 26 July 2016

Electronic supplementary material: The online version of this article (doi:10.1007/s10021-016-0018-7) contains supplementary material, which is available to authorized users.

Author contributions AM and PLS designed the experiment. AM, PLS conducted the experiment and analysed the samples. KR, PLS, AM analysed the results. KR wrote the first draft of the manuscript with all authors contributing to the final draft.

*Corresponding author; e-mail: kathrin.rousk@bio.ku.dk

\section{INTRODUCTION}

Nitrogen $(\mathrm{N})$ limits the productivity in subarctic and arctic ecosystems (Nadelhoffer and others 1992; Chapin and Shaver 1996) due to low N input via atmospheric deposition $\left(1-2 \mathrm{~kg} \mathrm{~N} \mathrm{ha}^{-1} \mathrm{y}^{-1}\right)$ (Van Cleve and Alexander 1981; Gundale and others 2011), slow $\mathrm{N}$ turnover in soils as a result of low temperatures and the accumulation of recalcitrant litter and plant material. Subarctic and arctic tundra harbour a substantial number of $\mathrm{N}_{2}$-fixer associations, representing different $\mathrm{N}_{2}$ fixation pathways, which are key for the $\mathrm{N}$ cycle by 
providing 'new' $\mathrm{N}$ to the ecosystem. Bacteria that fix atmospheric $\mathrm{N}_{2}$ (diazotrophs), thereby converting it into a plant accessible form (organic or inorganic $\mathrm{N}$ ), are present in N-limited ecosystems as free-living bacteria (heterotrophs and autotrophs) (Liengen and Olsen 1997; Hobara and others 2006), as moss-associated cyanobacteria (for example, Nostoc spp. with feather mosses; Ininbergs and others 2011) and as cyanobacterial phycobionts in lichens (for example, Peltigera) (Kallio and Kallio 1978). Furthermore, Sphagnum mosses are colonized by non-cyanobacterial $\mathrm{N}_{2}$-fixing associates (Larmola and others 2014). In addition, legumes (for example, Astragalus) form symbiotic relationships with nodule-forming, $\mathrm{N}_{2}$-fixing bacteria like Rhizobium. Accordingly, we distinguish henceforth between free-living diazotrophs not associated with plants, moss-associated diazotrophs, and diazotrophs forming symbiotic relationships in lichens and with legumes.

Although $\mathrm{N}_{2}$ fixation at the habitat level has been shown to differ between these $\mathrm{N}_{2}$-fixer associations (Rousk and others 2015), the fate of the fixed $\mathrm{N}_{2}$ remains unknown.

For instance, the contribution to habitat $\mathrm{N}_{2}$ fixation by the legume Astragalus alpinus was high $(>85 \%)$, despite its low ground cover in heaths in subarctic tundra, and the feather moss Hylocomium splendens did not contribute much to habitat $\mathrm{N}_{2}$ fixation $(15 \%)$ albeit its high groundcover. Surprisingly, few if any attempts have been made so far to quantify the transfer of fixed $\mathrm{N}_{2}$ via these pathways to other components in tundra ecosystems, and with that, the importance of different $\mathrm{N}_{2}$ fixer associations as sources of 'new' $\mathrm{N}$ for the ecosystem $\mathrm{N}$ pool.

Although legumes, some lichens, several mosses as well as free-living diazotrophs have the ability to fix atmospheric $\mathrm{N}_{2}$, their $\mathrm{N}$ input to the ecosystem might vary as a result of their different physiologies (see for example, Gavazov and others 2010). For instance, free-living $\mathrm{N}_{2}$ fixers easily leak fixed $\mathrm{N}_{2}$ into the surrounding soil (Belnap 2001), especially following disturbances (for example, dryingrewetting) and would more easily lose excess $\mathrm{N}$ due to their limited capacity to store nutrients. Similarly, given the close proximity of root nodules and surrounding soil, legumes likely lose more $\mathrm{N}$ to the soil than rootless lichens and mosses, whose connections to soil are limited and which decompose slowly (Hobbie 1996; Cornelissen and others 2007). In addition, mosses and lichens are extremely efficient in retaining and recycling acquired $\mathrm{N}$ (Oechel and Van Cleve 1986; Crittenden 1998; Aldous 2002; Rousk and others 2014) and there- fore regulate the amount and timing of $\mathrm{N}$ input to the system (see also Lindo and others 2013). These collective observations suggest that the range of $\mathrm{N}_{2}$ fixers in the subarctic differ fundamentally in timing and amount of $\mathrm{N}$ release to the ecosystems.

Nitrogen fixation is energetically "expensive" - 16 mol of ATP per 1 mol of $\mathrm{N}_{2}$ (Vitousek and Field 1999; Igarashi and Seefeldt 2003; Houlton and others 2008) and depends on carbon (C) availability or photosynthesis that provides the required energy (Paul and Clark 1996). For instance, $\mathrm{N}_{2}$ fixation in free-living cyanobacteria (Nostoc parmelioides) is linked to gross photosynthesis (Dodds 1989). Furthermore, if plants and associated diazotrophs trade $\mathrm{C}$ and $\mathrm{N}$ with each other, optimizing their nutrient status, C fixation and $\mathrm{N}_{2}$ fixation should be correlated. Similarly, photosynthesis in free-living cyanobacteria could cover the high energy demand of $\mathrm{N}_{2}$ fixation.

To deepen our knowledge about the coupling between autotrophic $\mathrm{C}$ and $\mathrm{N}_{2}$ fixation and to assess the short-term fate of fixed $\mathrm{N}_{2}$ in different $\mathrm{N}_{2}$ fixer associations (legume: Astragalus alpinus, lichen: Peltigera aphthosa, free-living: cyanobacterial crusts, moss: Sphagnum fuscum), we conducted a ${ }^{13} \mathrm{CO}_{2}-{ }^{15} \mathrm{~N}_{2}$ dual labelling field experiment in the subarctic and tracked the label into the $\mathrm{N}_{2}$-fixer associations as well as into other ecosystem components (non-diazotroph-associated plants, soil, microbes) three days and five weeks after the pulse labelling.

We hypothesized that (1) the retention and transfer of fixed $\mathrm{N}_{2}$ to the ecosystem differs between the $\mathrm{N}_{2}$ fixer types, with the following sequence in which the transfer of $\mathrm{N}$ to the system decreases from free-living cyanobacteria to mosses and lichens: free-living cyanobacteria $>$ legume $>$ moss-associated $=$ lichen, and (2) $\mathrm{N}_{2}$ and $\mathrm{C}$ fixation are positively correlated in the four investigated $\mathrm{N}_{2}$-fixer associations.

\section{Materials ANd Methods}

\section{Site Description and Sampling}

The experiment was established the 10th of July 2009 near the Abisko Scientific Research Station, Northern Sweden $\left(68^{\circ} \mathrm{N}, 18^{\circ} \mathrm{E}\right)$. The annual mean temperature is $-0.5^{\circ} \mathrm{C}$, the mean temperature in July is $11^{\circ} \mathrm{C}$ and the annual mean precipitation is $315 \mathrm{~mm}$ (30-year mean 1971-2001, http://polar. se/en/abisko-naturvetenskapliga-station/) (see also Figure S1 in the supplementary material).

Plots were selected in four subarctic vegetation types within an overall area of $0.5 \times 0.5 \mathrm{~km}$ close 
to Abisko Scientific Research Station: 1) A Sphagnum bog with an open cover of the dwarf shrub Empetrum hermaphroditum, 2) a heath dominated by the lichen Peltigera aphthosa, and the dwarf shrubs Empetrum hermaphroditum, Vaccinium uliginosum and Vaccinium vitis-idaea, 3) a polygon-patterned ground with open soil (caused by sediment and stone movements during winter) covered by cyanobacterial film (Liengen and Olsen 1997; Sorensen and others 2006), cryptogamic crust and scattered vascular plants such as Juncus, and 4) the narrow marginal transition zone between the patterned ground and a mixed dwarf shrub heath, with the legume Astragalus alpinus and some grasses (Figure S2). The water table is low at these sites, at least $40 \mathrm{~cm}$ below the soil surface.

Six replicate plots were randomly selected within each vegetation type with a homogenous cover and dominance of the $\mathrm{N}_{2}$-fixer associations and were at least $0.5 \mathrm{~m}$ apart from each other. The four different $\mathrm{N}_{2}$-fixer associations (Astragalus alpinus; Peltigera aphthosa; cyanobacterial crust $=$ upper $5 \mathrm{~mm}$ cyanobacterial film on top of the soil; Sphagnum fuscum) including the adjacent vegetation were subjected to ${ }^{13} \mathrm{C}$, and ${ }^{15} \mathrm{~N}$ labelling (see below).

\section{Experimental Set-Up and In Situ Labelling}

To investigate the short-term fate of fixed $\mathrm{N}_{2}$ in subarctic tundra, we used in situ ${ }^{15} \mathrm{~N}-\mathrm{N}_{2}$ pulse labelling of a range of $\mathrm{N}_{2}$-fixer associations and followed the label into different pools of the ecosystem. At the same time, we used in situ ${ }^{13} \mathrm{C}$ $\mathrm{CO}_{2}$ labelling in the same plots to identify the link between $\mathrm{N}_{2}$ and $\mathrm{C}$ fixation and to assess photosynthesis in the different plots. In each of the four $\mathrm{N}_{2}$-fixer associations, 12 carefully cut mesocosm cores containing the intact $\mathrm{N}_{2}$ fixers, adjacent vegetation and soil were placed in transparent plastic containers and a vial with lactic acid/glycerine mix was added after which the containers were replaced in the hole where the plant-soil mesocosms were collected (Figure S2). Given the much lower vegetation height in the cyanobacterial crust plots and to ensure similar conditions in the different $\mathrm{N}_{2}$ fixer plots, we used containers half the volume of the diazotroph-associated plant plots for the cyanobacterial crust plots, so that the headspace in the container above the vegetation was the same in all vegetation types. The containers had a diameter of $10 \mathrm{~cm}$, and a volume of $1 \mathrm{l}$ or $0.5 \mathrm{l}$, for the diazotroph-associated plants and cyanobacterial crust plots, respectively. To prevent over-pressure in the containers, $100 \mathrm{ml}$ air was removed and $7 \mathrm{mg} \mathrm{Na}_{2}^{13} \mathrm{CO}_{3}(99 \%$ enriched) dissolved in water was injected in the vial with lactic acid, resulting in the release of ${ }^{13} \mathrm{C}_{-}-\mathrm{CO}_{2}$ similar to an addition of $0.10 \mathrm{~g}^{13} \mathrm{C} \mathrm{m}^{-2}$. This corresponded to an increase in the headspace $\mathrm{CO}_{2}$ concentration from ambient $(400 \mathrm{ppm})$ to $587 \mathrm{ppm} \mathrm{CO}_{2}$. Although this could lead to enhanced photosynthesis (Körner and Diemer 1987), arctic-alpine plants respond little to elevated $\mathrm{CO}_{2}$, and even $\mathrm{N}_{2}$ fixation in legumes is unaffected (as reviewed in Körner 2003). In the cyanobacterial crust plots, only four of the six replicates were labelled and used for subsequent analyses due to lack of ${ }^{13} \mathrm{C}$ label brought to the field site. Eighty $\mathrm{ml}{ }^{15} \mathrm{~N}-\mathrm{N}_{2}(98 \%$ enriched) was directly injected into the same containers and incubated for $24 \mathrm{~h}$. This resulted in a total addition of $13.8 \mathrm{~g}^{15} \mathrm{~N} \mathrm{~m}^{-2}$ during the $24 \mathrm{~h}$, after which the lid was removed until harvest.

\section{Harvest and Sample Analyses}

Three days (13th of July 2009) and five weeks (19th of August 2009) after the pulse labelling, six cores per site and sampling date were harvested by separating aboveground and belowground plant parts, which were sorted into different species, dried and weighed. In addition, the soils were sampled. In the legume plots, Astragalus plants were further divided into leaves, young sprouts, rhizobia and roots and analysed for ${ }^{13} \mathrm{C},{ }^{15} \mathrm{~N}$ enrichment, as was also done for the remaining constituents in the same plots (diazotroph-associated lichens, Empetrum, other evergreen shrubs, deciduous shrubs, grass, Sphagnum/cyanobacterial crust, non-diazotroph-associated lichens, Equisetum, herbs, bulk soil and unspecified roots and stems). The same fractions were harvested and analysed in the lichen, cyanobacterial crust and moss plots. The organic material in the moss plots was peat, and not soil. However, for an easier read and comparison, we refer to "soil" in all plots. The soil was homogenized and subjected to chloroform fumigation extraction and analysis as in Sorensen and others (2008) and Larsen and others (2012) (Appendix S1).

Plant and soil material was dried, milled and analysed for ${ }^{15} \mathrm{~N} /{ }^{14} \mathrm{~N}$ and ${ }^{13} \mathrm{C} /{ }^{12} \mathrm{C}$ as well as for total nitrogen and carbon content using an Isoprime isotope ratio mass spectrometer (Isoprime Ltd., UK) coupled to an Eurovector $\mathrm{CN}$ analyzer. Plant and soil samples for analyses of ${ }^{13} \mathrm{C}$ and ${ }^{15} \mathrm{~N}$ natural abundances were collected three days after the second harvest $\left(22^{\text {th }}\right.$ of August 2009) to calculate enrichment and recovery of the added label. The amount of ${ }^{15} \mathrm{~N}$ and ${ }^{13} \mathrm{C}$ in the microbial biomass 
was analysed by IRMS after freeze drying the fumigated and non-fumigated extracts.

We refer to the ${ }^{15} \mathrm{~N}$ and ${ }^{13} \mathrm{C}$ pools in each fraction three days after labelling as incorporation (fixation and turnover) and five weeks after labelling as accumulation (accumulation and storage). For an estimate of ${ }^{15} \mathrm{~N}$ recovery and to identify the distribution of the label within the plots, we set the total ${ }^{15} \mathrm{~N}$ within a plot to $100 \%$ and rescaled the tracer recovery in each pool. We use the term recovery here as a combination of the fixation of ${ }^{15} \mathrm{~N}$ and ${ }^{13} \mathrm{C}$ and the recovery of the label.

\section{Environmental Conditions}

The air temperature during the course of the experiment ranged from 5.5 to $18^{\circ} \mathrm{C}$ (mean and SE: $13.0 \pm 0.6^{\circ} \mathrm{C}$ ) and was $12.6^{\circ} \mathrm{C}$ at the day of the label addition $(10.07 .09), 13.7^{\circ} \mathrm{C}$ at the first sampling (13.07.09) and $5.5^{\circ} \mathrm{C}$ at the second sampling (19.08.09) (Figure Sla). The total daily precipitation was $6.6,0.1$ and $0.1 \mathrm{~mm}$ on the day of label addition, three days and five weeks after the label addition, respectively (Figure Slb). Soil temperatures in the first $5 \mathrm{~cm}$ ranged between $7^{\circ} \mathrm{C}$ and $12^{\circ} \mathrm{C}$ during the experiment $\left(9.4 \pm 0.2^{\circ} \mathrm{C}\right.$ ) (Figure Sla).

\section{Statistical Analyses}

To test for differences between ${ }^{15} \mathrm{~N}$ and ${ }^{13} \mathrm{C}$ incorporation and accumulation in the ecosystem components within the plots in the different vegetation types and between the two sampling times we used two-way ANOVAs, with vegetation type and date as factors and interactions between them included, followed by Tukey's Post Hoc Test. The same analyses were performed with the soil and microbial data (inorganic $\mathrm{N}$, total dissolved $\mathrm{N}$ (TDN), total carbon (TC), C:N ratios). Correlation between ${ }^{15} \mathrm{~N}$ and ${ }^{13} \mathrm{C}$ enrichment in the $\mathrm{N}_{2}$-fixer associations was analysed with linear regression including date as factor. All data analyses were performed in R 3.0.3. (2014).

\section{Results}

\section{Plant, Soil and Soil Microbial C and N Contents}

Total tissue $\mathrm{N}$ content of the $\mathrm{N}_{2}$-fixer associations was similar at the two sampling times but was significantly higher in the lichen than in the other three $\mathrm{N}_{2}$-fixer associations $\left(12.1 \pm 2.1 \mathrm{~g} \mathrm{~m}^{-2}\right.$; $3.0 \pm 0.3 \mathrm{~g} \mathrm{~m}^{-2} ; 4.5 \pm 1.0 \mathrm{~g} \mathrm{~m}^{-2} ; 4.0 \pm 0.5 \mathrm{~g} \mathrm{~m}^{-2}$ for lichen, legume, cyanobacterial crust and moss, respectively) $\left(\mathrm{F}_{1,3}=18.9 ; P<0.0001\right)$ (Figure $\left.\mathrm{S} 3\right)$.
Soil $\mathrm{C}$ and $\mathrm{N}$ differed significantly between the vegetation types $\left(F_{1,3}=40.8 ; P<0.0001\right.$; Table 1$)$ and were highest in the lichen and lowest in cyanobacterial crust plots. Nitrate concentrations in soils from all vegetation plots were low, ranging between 0 and $0.3 \mu \mathrm{g} \mathrm{g}^{-1}$ (Table 1) with the lowest concentrations in the lichen and moss plots $\left(\mathrm{F}_{1,3}=5.7 ; P=0.003\right)$. No differences in $\mathrm{NH}_{4}{ }^{+}-\mathrm{N}$ concentrations between the vegetation types or date of sampling were found. Soil C:N was highest in the moss plots $(82 \pm 9$ and less than 30 for the moss and the other $\mathrm{N}_{2}$ fixer plots, respectively, $\left.F_{1,3}=37.8 ; P<0.0001\right)$. Total dissolved $\mathrm{N}(\mathrm{TDN})$ was significantly lower in the cyanobacterial crust compared to the other plots $\left(F_{1,3}=12.7\right.$; $P<0.0001$ ), and the moss plots had lower TDN concentrations than the lichen plots $(F=5.0$; $P=0.03 ; \mathrm{df}=3$ ), with no differences between the sampling times. Soil microbial $\mathrm{N}$ was lowest in the cyanobacterial crust plots compared to the other plots $\left(F_{1,3}=15.16 ; P=0.0001\right)$ and microbial $\mathrm{C}$ showed a similar pattern $\left(F_{1,3}=18.9 ; P=0.0001\right)$ and did not change over the course of the experiment. Microbial C:N ratio was higher in the moss than in the legume and cyanobacterial crust plots (Table 1).

\section{${ }^{15} \mathrm{~N}$ and ${ }^{13} \mathrm{C}$ Incorporation and Accumulation in Soil and Microbes}

The incorporation and accumulation of ${ }^{15} \mathrm{~N}$ in soils did not differ in regard to sampling date but was higher in the legume plots than in the other plots $\left(F_{1,3}=10.1 ; P=0.0001 ;\right.$ Fig. 1$)$. Also, ${ }^{15} \mathrm{~N}$ incorporation into soils in the legume plots was similar to the ${ }^{15} \mathrm{~N}$ incorporation in the legume itself when the values for both dates were combined (103.7 $\pm 18.5 ; 107.8 \pm 4.8 \mathrm{mg}{ }^{15} \mathrm{~N} \mathrm{~g}^{-1} \mathrm{~m}^{-2}$ for soil and legume, respectively). ${ }^{15} \mathrm{~N}$ incorporation into the microbial biomass was highest in the legume plots 3 days after labelling $\left(F_{1,3}=3.0 ; P=0.04\right)$ and ${ }^{15} \mathrm{~N}$ accumulation decreased after 5 weeks $\left(F_{1,3}=5.0 ; \quad P=0.008\right)$, whereas microbial ${ }^{15} \mathrm{~N}$ accumulation in the other plots did not change with time (Figure 2). After three days, the transfer of ${ }^{15} \mathrm{~N}$ to the microbial biomass made up $0.5 \%$ of total incorporated ${ }^{15} \mathrm{~N}$ both in the legume and in the cyanobacterial crust plots, but only 0.01 and $0.02 \%$ in the lichen and moss plots. Five weeks after labelling, ${ }^{15} \mathrm{~N}$ recovery in the microbial biomass was much lower in the legume $(0 \%)$, and still higher in the cyanobacterial crust $(0.24 \%)$ than in the lichen $(0.10 \%)$ and moss $(0.07 \%)$ plots, albeit there was an increase in these plots with time (Figure S4a). 


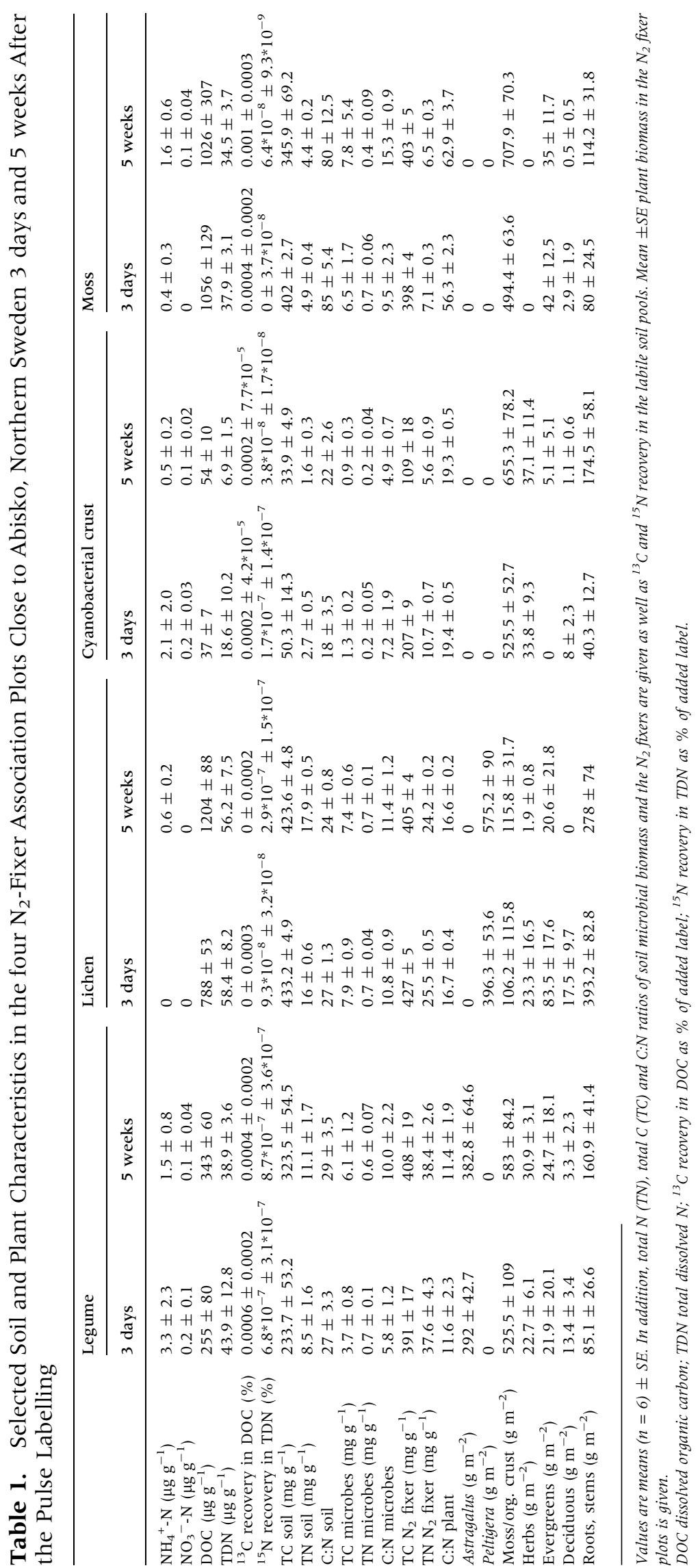



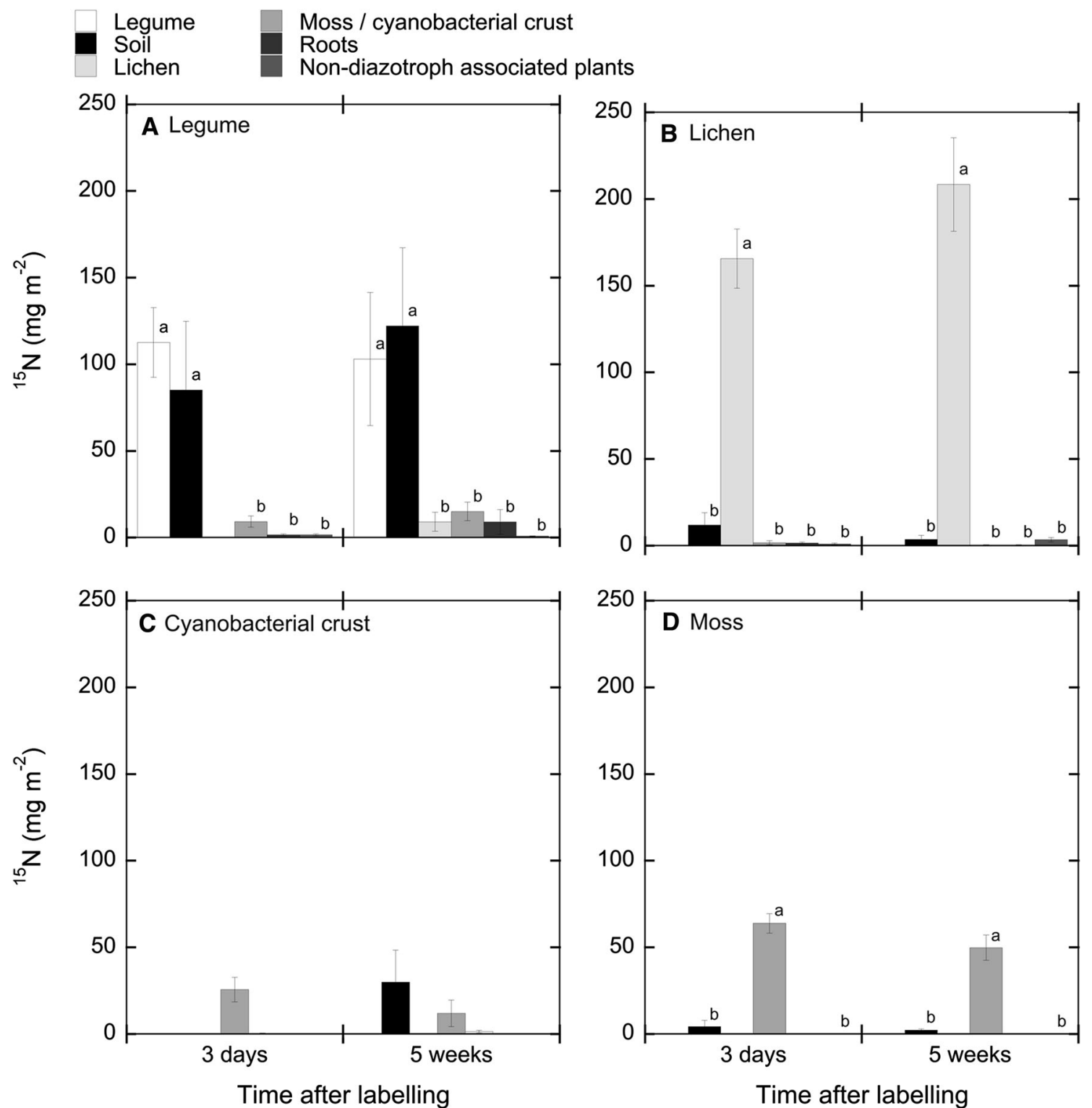

Fig. $1 .{ }^{15} \mathrm{~N}$ incorporation and accumulation $\left(\mathrm{mg} \mathrm{m}^{-2}\right)$ in the four $\mathrm{N}_{2}$-fixer associations (A Legume, B Lichen, C Cyanobacterial crust, D Moss). Shown is the amount in the $\mathrm{N}_{2}$-fixer associations as well as in the ecosystem components (soil, roots, non-diazotroph-associated plants = shrubs, herbs, graminoids, horsetail, unspecified stems) present in the plots 3 days (incorporation) as well as 5 weeks (accumulation) after the pulse labelling. Values are means $(n=6) \pm \mathrm{SE}$. Please see legend for label explanation of the fractions. Lower case letters indicate significant differences in ${ }^{15} \mathrm{~N}$ incorporation between the ecosystem components, based on Tukey's HSD pairwise comparisons. The statistical results are shown in the figures unless there was a sampling time effect; in this case, the statistical results are given in the text.

Incorporation and accumulation of ${ }^{13} \mathrm{C}$ into the soil collected in the cyanobacterial crust plots was close to natural abundance levels at both sampling dates, and thus, much and significantly lower than in the other vegetation types $\left(F_{1,3}=5.39\right.$; $P=0.003$; Fig. 3). Three days after labelling, ${ }^{13} \mathrm{C}$ incorporation into the microbial biomass was highest in the cyanobacterial crust plots and lowest in the lichen plots $\left(F_{1,3}=6.5 ; P=0.001\right) .{ }^{13} \mathrm{C}$ accumulation was significantly lower 5 weeks after the label addition in the cyanobacterial crust plots $\left(F_{1,3}=10.61 ; P=0.002\right)$. Three days after labelling, ${ }^{13} \mathrm{C}$ recovery in the microbial biomass as fraction of ecosystem recovery was highest in the cyanobacterial crust plots $(1.8 \%)$, similar in the moss $(0.53 \%)$ and legume $(0.52 \%)$ plots and lowest in the lichen plots $(0.24 \%) .{ }^{13} \mathrm{C}$ recovery was lower 5 weeks after the label addition in the 

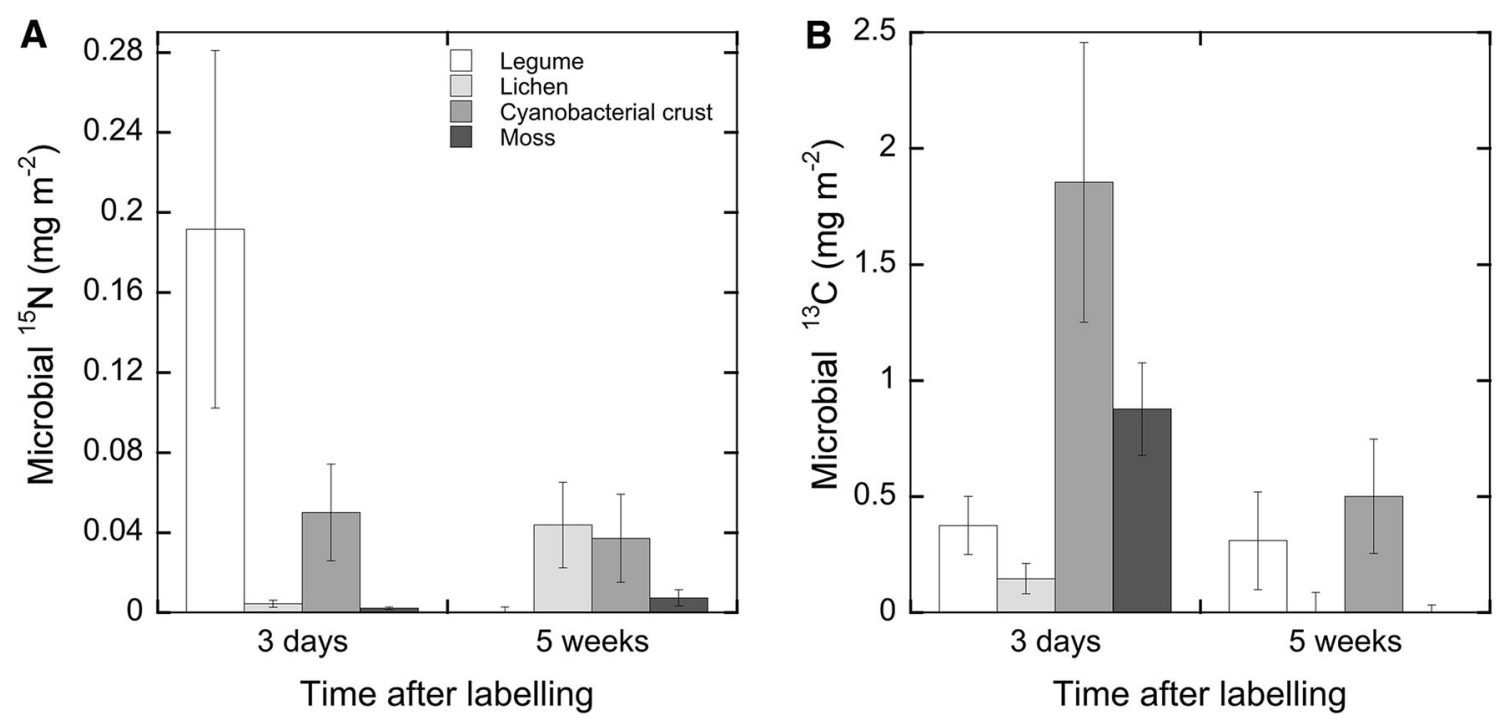

Fig. 2. $\mathbf{A}{ }^{15} \mathrm{~N}$ and $\mathbf{B}{ }^{13} \mathrm{C}$ accumulation $\left(\mathrm{mg} \mathrm{m}^{-2}\right)$ in the microbial biomass in the four different $\mathrm{N}_{2}$-fixer associations (Legume: white bars, Lichen: light grey bars, Cyanobacterial crust: medium grey bars; Moss: dark grey bars) 3 days (incorporation) and 5 weeks (accumulation) after the pulse labelling. Please note the differences in the y-axes. The results of the statistical tests are given in the text.

cyanobacterial crust $(0.71 \%)$, lichen $(0 \%)$ and moss $(0 \%)$ plots (Figure $\mathrm{S} 4 \mathrm{~b})$.

\section{Total Plot Uptake of ${ }^{15} \mathrm{~N}$ and ${ }^{13} \mathrm{C}$}

The total ${ }^{15} \mathrm{~N}$ uptake at plot level was similar between the two sampling dates, but differed between the $\mathrm{N}_{2}$ fixer plots: the total ${ }^{15} \mathrm{~N}$ accumulation ( $\mathrm{N}_{2}$ fixation, turnover and storage) was far higher in the legume (means for both dates \pm SE: $39.1 \pm 14.5 \mathrm{mg}^{15} \mathrm{~N} \mathrm{~m}^{-2}$ ) and lichen plots $\left(33.2 \pm 20.9 \mathrm{mg}{ }^{15} \mathrm{~N} \mathrm{~m}^{-2}\right)$ than in the cyanobacterial crust $\left(5.8 \pm 3.1 \mathrm{mg}{ }^{15} \mathrm{~N} \mathrm{~m}^{-2}\right)$ and moss $\left(10.0 \pm 6.4 \mathrm{mg}{ }^{15} \mathrm{~N} \mathrm{~m}^{-2}\right)$ plots $\left(F_{1,3}=5.31\right.$; $P=0.001$; Fig. 1).

${ }^{13} \mathrm{C}$ accumulation (photosynthesis minus respiratory loss of ${ }^{13} \mathrm{C}$ ) was not different between the two sampling dates, but it was highest in the moss plots $\quad(0.5 \pm 0.1 ; \quad 0.4 \pm 0.1 ; \quad 0.2 \pm 0.06$; $0.8 \pm 0.4 \mathrm{~g}^{13} \mathrm{C} \mathrm{m}^{-2}$, for legume, lichen, cyanobacterial crust and moss plots, respectively) $\left(F_{1,3}=12.78 ; P<0.0001\right.$; Fig. 3$)$.

\section{${ }^{15} \mathrm{~N}$ and ${ }^{13} \mathrm{C}$ Incorporation and Accumulation in the $\mathrm{N}_{2}$-Fixer Associations}

Between sampling times, no significant differences in ${ }^{15} \mathrm{~N}$ incorporation and accumulation in any of the four $\mathrm{N}_{2}$-fixer associations were found. But ${ }^{15} \mathrm{~N}$ incorporation and accumulation was higher in the lichen than in the cyanobacterial crust and moss
$\left(F_{1,3}=5.9 ; P=0.001\right)$, and was distributed differently among ecosystem compartments in the four habitats (Fig. 1). The amount of $\mathrm{N}_{2}$ fixed was lowest in the cyanobacterial crust plots $\left(0.6 \pm 0.1 \mathrm{~kg} \mathrm{~N} \mathrm{ha}^{-1} \mathrm{y}^{-1}\right)$, followed by the moss $\left(1.0 \pm 0.1 \mathrm{~kg} \mathrm{~N} \mathrm{ha}^{-1} \mathrm{y}^{-1}\right)$, and was highest in the lichen $\left(3.5 \pm 0.4 \mathrm{~kg} \mathrm{~N} \mathrm{ha}^{-1} \mathrm{y}^{-1}\right)$ and legume plots $\left(4.2 \pm 1.0 \mathrm{~kg} \mathrm{~N} \mathrm{ha}^{-1} \mathrm{y}^{-1}\right)$, assuming half a year of no activity due to winter conditions.

Incorporation and accumulation of ${ }^{13} \mathrm{C}$ was similar between the sampling times, and was highest in the moss $\left(3.7 \pm 0.2 \mathrm{~g}^{13} \mathrm{C} \mathrm{m}^{-2} \mathrm{day}^{-1}\right)$ $\left(F_{1,3}=52.9 ; P<0.0001\right.$; Fig. 3$)$.

\section{Total Recovery of ${ }^{15} \mathrm{~N}$ at Ecosystem Level: Transfer to Soil and Non-diazotroph- Associated Plants}

The ${ }^{15} \mathrm{~N}$ recovery as plot-specific total uptake in the $\mathrm{N}_{2}$-fixer associations was similar three days and five weeks after labelling in the legume (42 vs. $44 \%$ ), lichen (88 vs. $91 \%$ ) and moss (99\% both times) (Fig. 4). However, ${ }^{15} \mathrm{~N}$ recovery in the cyanobacterial crust decreased from $96 \%$ after three days to $30 \%$ after five weeks of labelling, whereas the recovery in the soil increased from 0 to $66 \%$ (Fig. 4). The recovery of ${ }^{15} \mathrm{~N}$ in the soil from the legume plots remained similar throughout the experiment and was similar to that in the legume itself ( 47 vs. $40 \%, 3$ days vs. 5 weeks after labelling). 

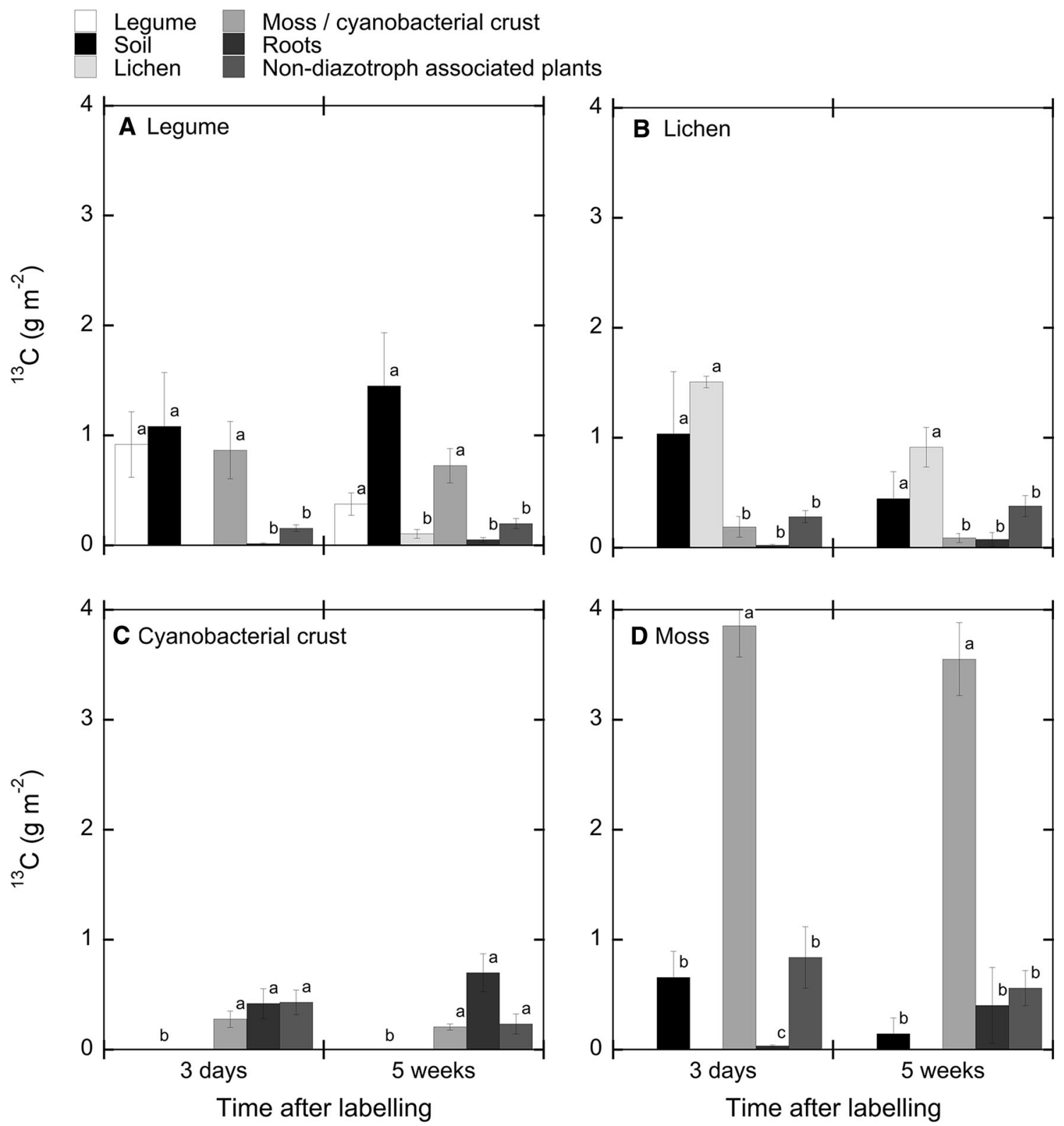

Fig. 3. ${ }^{13} \mathrm{C}$ incorporation and accumulation $\left(\mathrm{g} \mathrm{m}^{-2}\right.$ ) in the four $\mathrm{N}_{2}$-fixer associations (A Legume, B Lichen, C Cyanobacterial crust, D Moss). Shown is the amount in the $\mathrm{N}_{2}$-fixer associations as well as in the ecosystems components present in the plots three days (incorporation) as well as 5 weeks (accumulation) after the pulse labelling. Values are means $(n=6, n=4$ for the cyanobacterial crust plots) \pm SE. Please see legend for label explanation of the fractions. Lower case letters indicate significant differences in ${ }^{13} \mathrm{C}$ incorporation between the ecosystem components, based on Tukey's HSD pairwise comparisons. The statistical results are shown in the figures unless there was a sampling time effect; in this case, the statistical results are given in the text.

The ${ }^{15} \mathrm{~N}$ recovery in the non-diazotroph-associated plants was small. Shortly after labelling, the non-diazotroph-associated plants contained 3.7\% of total ecosystem ${ }^{15} \mathrm{~N}$ in the legume, $2.0 \%$ in the cyanobacterial crust, $1.1 \%$ in the lichen and only $0.3 \%$ in the moss plots (Fig. 1, 4).

\section{Correlation Between ${ }^{15} \mathrm{~N}$ and ${ }^{13} \mathrm{C}$ Enrichment in the $\mathrm{N}_{2}$-Fixer Associations}

${ }^{15} \mathrm{~N}$ and ${ }^{13} \mathrm{C}$ enrichment in the lichen were significantly correlated three days after labelling $\left(P=0.03 ; R^{2}=0.70\right)$, and five weeks after labelling 
Soil Moss / cyanobacterial crust

Roots $\square$ Non-diazotroph associated plants

A

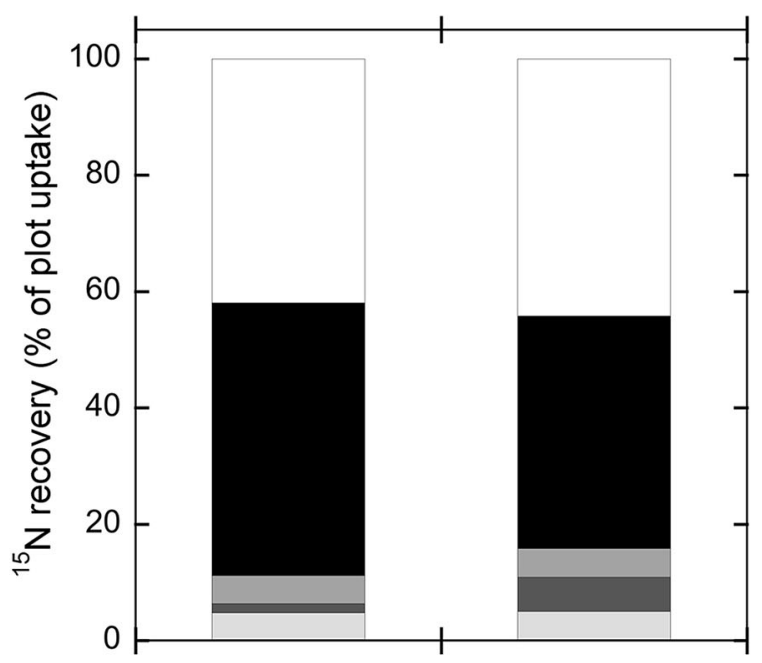

C

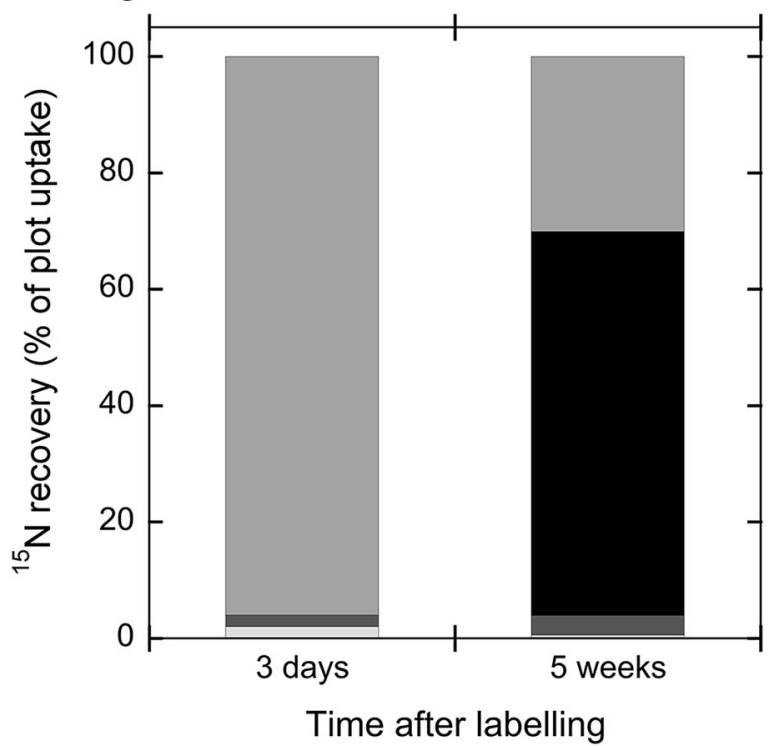

B

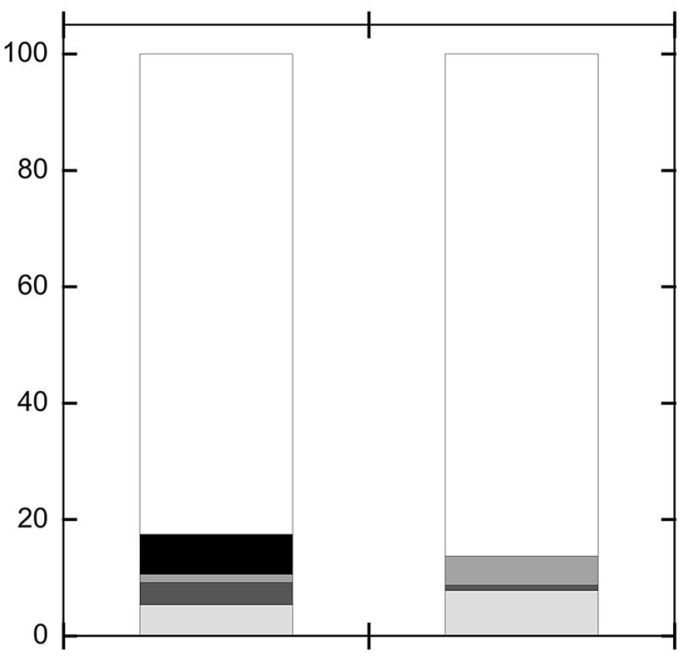

D

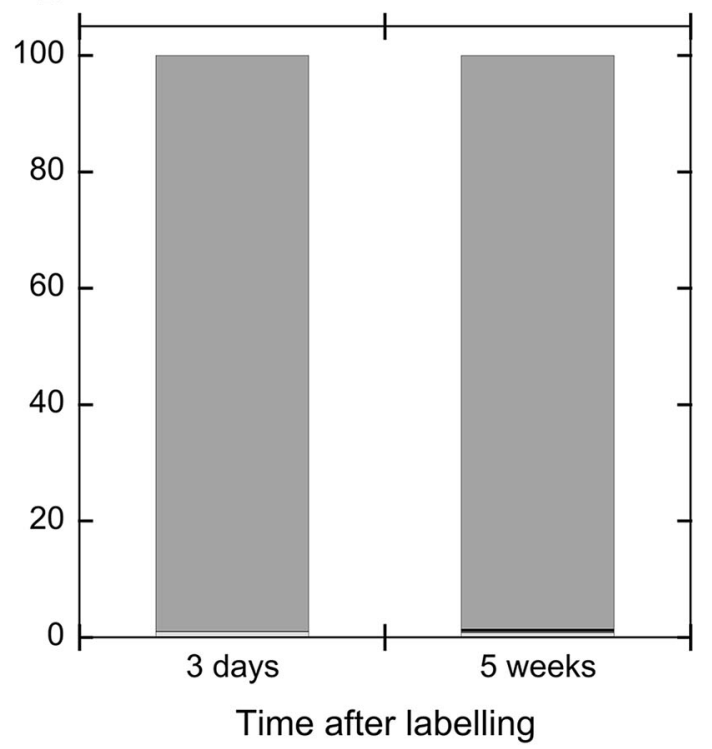

Fig. 4. ${ }^{15} \mathrm{~N}$ recovery in the four different $\mathrm{N}_{2}$-fixer associations (A Legume, B Lichen, C Cyanobacterial crust, D Moss). Shown is the recovery as \% of total plot uptake 3 days (incorporation) as well as five (accumulation) weeks after the pulse labelling in the $\mathrm{N}_{2}$-fixer associations as well as in the ecosystems components (soil, roots, non-diazotroph-associated plants = shrubs, herbs, graminoids, horsetail, unspecified stems). Please see legend for label explanation of the fractions.

in the cyanobacterial crust $\left(P=0.04 ; R^{2}=0.88\right)$. In the moss, ${ }^{15} \mathrm{~N}$ and ${ }^{13} \mathrm{C}$ enrichment were significantly correlated at both sampling dates $(P=0.03$; $R^{2}=0.68$ and $P=0.02 ; R^{2}=0.643$ days and 5 weeks after sampling, respectively), whereas no significant relationship was found for the legume (Fig. 5).

\section{Discussion}

\section{The Fate of Fixed $\mathrm{N}_{2}$}

Our study provides novel insights into the shortterm fate of fixed $\mathrm{N}_{2}$ by the key $\mathrm{N}_{2}$-fixer associations in subarctic tundra. Long-term fertilizer addition and warming of several vegetation types 

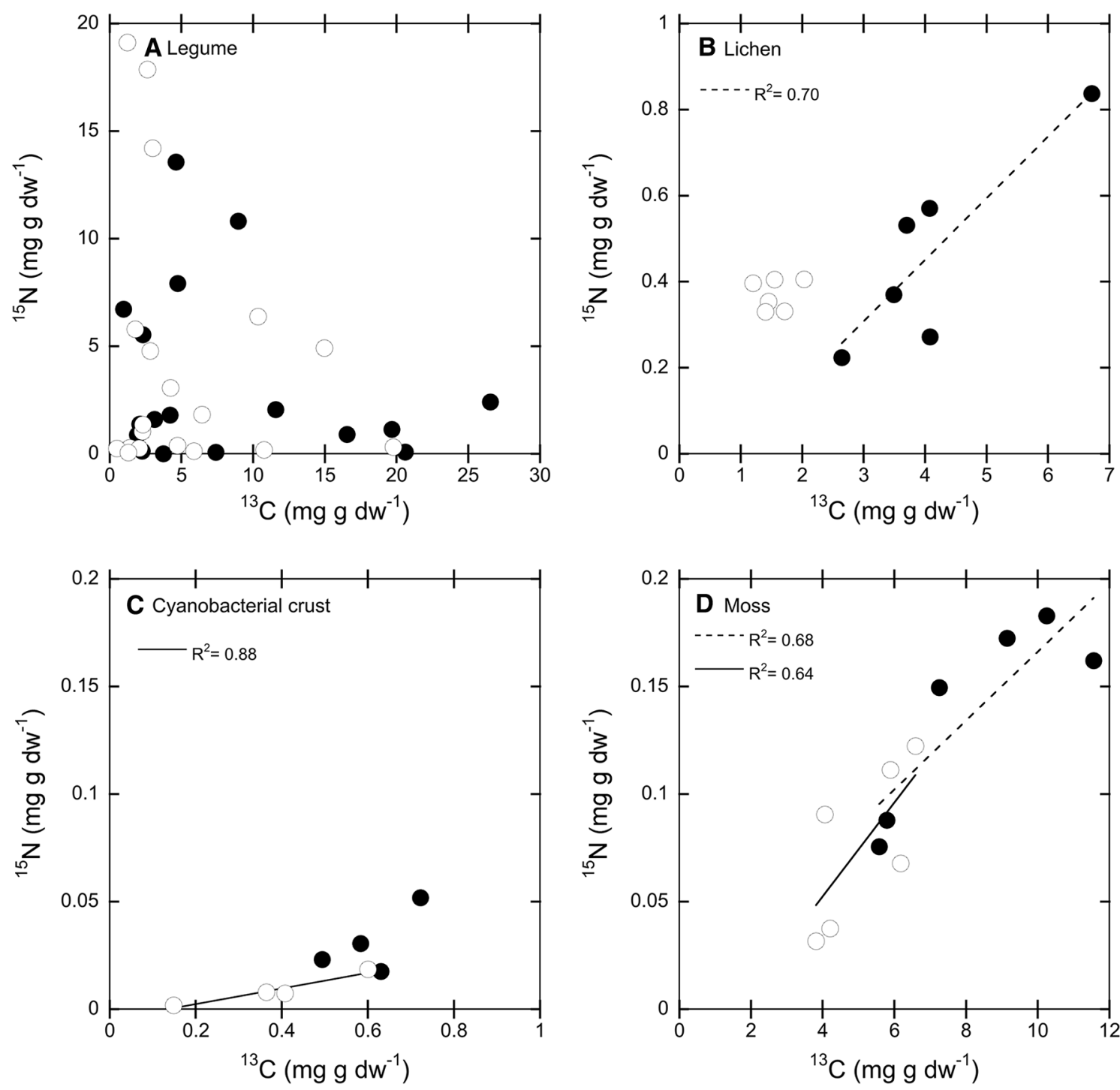

Fig. 5. Relationship between ${ }^{15} \mathrm{~N}\left(\mathrm{mg} \mathrm{g} \mathrm{dw}^{-1}\right)$ and ${ }^{13} \mathrm{C}\left(\mathrm{mg} \mathrm{g} \mathrm{dw}^{-1}\right)$ incorporation and accumulation in the four investigated $\mathrm{N}_{2}$-fixer associations. Data points are from both sampling campaigns: 3 days (black circles) and 5 weeks (open circles) after the labelling. For the legume, accumulation in aboveground as well as in belowground plant parts are shown $(n=28)$. $N=6$ for lichen and moss, and $n=4$ for the cyanobacterial crust plots for each sampling date. Please note the different ranges in the $y$ - and $x$-axes. Significant $(P<0.05)$ linear regressions, separated by date, are plotted.

close to our study sites has demonstrated $\mathrm{N}$ and temperature limitation of heath vegetation (Michelsen and others 2012). Here, $\mathrm{N}$ can be provided through $\mathrm{N}_{2}$ fixation by a wide range of diazotroph associations, which, as we show here, fix $\mathrm{N}_{2}$ at rates that differ between vegetation types, with higher $\mathrm{N}_{2}$ fixation rates in the legume Astragalus $\left(4.2 \pm 1 \mathrm{~kg} \mathrm{~N} \mathrm{ha}^{-1} \mathrm{y}^{-1}\right)$ and the lichen Peltigera $\left(3.5 \pm 0.4 \mathrm{~kg} \mathrm{~N} \mathrm{ha}^{-1} \mathrm{y}^{-1}\right)$ than in the cyanobacterial crust $\left(0.6 \pm 0.1 \mathrm{~kg} \mathrm{~N} \mathrm{ha}^{-1} \mathrm{y}^{-1}\right)$ and the moss Sphagnum $\left(1.0 \pm 0.1 \mathrm{~kg} \mathrm{~N} \mathrm{ha}^{-1} \mathrm{y}^{-1}\right)$. Those rates are comparable to previously reported values for $\mathrm{N}_{2}$ fixation in the subarctic, ranging between 0.3 and
$4 \mathrm{~kg} \mathrm{~N} \mathrm{ha}^{-1} \mathrm{y}^{-1}$ (Longton 1997; Sorensen and Michelsen 2011). In comparison, atmospheric N deposition in these areas is below $2 \mathrm{~kg} \mathrm{~N} \mathrm{ha}^{-1} \mathrm{y}^{-1}$ (Van Cleve and Alexander 1981); thus $\mathrm{N}_{2}$ fixation in subarctic tundra can easily exceed $\mathrm{N}$ input from atmospheric deposition. Given the short vegetation period in subarctic tundra that requires quick assimilation of $\mathrm{N}$ and other nutrients to ensure growth after snowmelt, the short-term fate of $\mathrm{N}$ can affect the yearly production fundamentally. Furthermore, microbial growth is most commonly limited by the availability of $\mathrm{C}$, thus plant $\mathrm{C}$ drives the microbial $\mathrm{N}$ loop in soils (Knops and others 
2002). In N-limited subarctic and arctic ecosystem however, even microbes might be limited by $\mathrm{N}$ (Sistla and Schimel 2012), and rely on the $\mathrm{N}$ input from $\mathrm{N}_{2}$ fixers. Therefore, the $\mathrm{N}$ cycle will vary greatly depending on the diazotrophs present, which differ fundamentally in fixation rates as well as in the timing and amount of $\mathrm{N}$ released. In accordance with our first hypothesis, both the lichen and the moss retained the fixed $\mathrm{N}_{2}$ over five weeks and did not release any significant amounts of ${ }^{15} \mathrm{~N}$ to the surrounding soil and non-diazotrophassociated plants (see also for example, Oechel and Van Cleve 1986). The fixed $\mathrm{N}_{2}$ in mosses and lichens is likely only released upon disturbances like freeze-thaw events (Larsen and others 2007, 2012) and drying-rewetting events (Carleton and Read 1991), which lead to compromised membrane integrity resulting in leaching of nutrients. In contrast, in the legume plots, half of the fixed ${ }^{15} \mathrm{~N}$ was recovered in the soil shortly after the labelling, suggesting that transfer of fixed $\mathrm{N}_{2}$ from the rhizobia to the surrounding soil including the microbes occurred. We cannot exclude that the soil fraction includes small fine root and lichen fractions as well as tiny rhizobial root nodules, which could not be separated sufficiently from the soil. Alternatively, heterotrophic $\mathrm{N}_{2}$ fixation could have contributed to the ${ }^{15} \mathrm{~N}$ enrichment in the legume soils. However, if heterotrophs were responsible for $\mathrm{N}_{2}$ fixation in these habitats, we would expect similar contribution in the other $\mathrm{N}_{2}$ fixer plots, which were situated next to the legume plots (see Figure S2), but this was not the case. In addition, legumes contribute most to habitat $\mathrm{N}_{2}$ fixation in dry as well as wet heaths in subarctic tundra (Rousk and others 2015).

The ${ }^{15} \mathrm{~N}$ recovery in the legume and lichen plots were very variable which may be a result of high variation in biomass and ${ }^{15} \mathrm{~N}$ enrichment in the dominant $\mathrm{N}_{2}$ fixers, emphasizing the patchiness of arctic ecosystems, with high variation on small scales (Stewart and others 2011, 2014).

The free-living cyanobacteria seemed to release most of the fixed ${ }^{15} \mathrm{~N}_{2}$ into the soil within 5 weeks. In accordance with that, $\mathrm{N}_{2}$-fixing soil crusts may release $5-70 \%$ of fixed $\mathrm{N}_{2}$ within 2 days to the surrounding soil, and the release is greater when the conditions are not optimal (for example, temperature, drying-rewetting events) (Millbank 1978; Belnap 2001). In addition, in low $\mathrm{N}$ environments, free-living cyanobacteria might lose nutrients via diffusion (Dodds and others 1995). The rain event prior the second sampling (Figure Slb) could have washed microbes away in the cyanobacterial crust, as microbial $\mathrm{C}$ was slightly lower at the second harvest, or led to a loss of $\mathrm{N}$ via leaching or via increased microbial activity upon the rain event, which could have freed-up nutrients, but on the other hand, the microbial $\mathrm{N}$ was unchanged. Losses via denitrification cannot be ruled out, however, the low nitrate concentrations in the soils (Table 1) would not promote $\mathrm{N}_{2} \mathrm{O}$ production. Further, denitrification rates in similar ecosystem types close to our study sites were below the detection limit (Sorensen and others 2006).

Lichen tissue, the soil in the same plots as well as soils in the legume plots had high $\mathrm{N}$ concentrations (Figure S3; Table 1), indicating high $\mathrm{N}_{2}$ fixation activity, and release of fixed $\mathrm{N}_{2}$ from rhizobia into the surrounding soil via leaching and root exudation in the legume plots. Additionally, the N-rich litter of the legume would promote decomposition (Høgh-Jensen 2006). The soils in the moss plots had low $\mathrm{N}$ and high $\mathrm{C}$ contents, indicative of slow decomposition and nutrient cycling in the acidic and cold environment (Fenton and others 2010).

The low ${ }^{15} \mathrm{~N}$ accumulation in the non-diazotroph-associated plants suggests that the $\mathrm{N}_{2}$ fixed by the four investigated $\mathrm{N}_{2}$ fixers is not readily available for the non-diazotroph-associated plants in the ecosystems. Nevertheless, fractions of ecosystem ${ }^{15} \mathrm{~N}$ recovery in soils, microbes and nondiazotroph-associated plants were higher in the legume and cyanobacterial crust plots than in the lichen and moss plots. In subarctic habitats, cyanobacteria and legumes might present shortterm sources of available $\mathrm{N}$, whereas mosses and lichens represent short-term $\mathrm{N}$ sinks (see for example, Rousk and others 2014; Stewart and others 2014). Mosses can store $\mathrm{N}$ and $\mathrm{C}$ in recalcitrant pools (for example, Woodin and others 2009), rendering them unavailable for months or even years (for example, Rousk and others 2014).

Hardly any study followed ${ }^{15} \mathrm{~N}-\mathrm{N}_{2}$ into $\mathrm{N}_{2}$ fixers and into other ecosystem components. Therefore, comparisons with previous results are difficult. However, Mohr and others (1998) incubated alfalfa for 7 weeks with ${ }^{15} \mathrm{~N}-\mathrm{N}_{2}$ and recovered $5 \%$ of the total ${ }^{15} \mathrm{~N}$ in the microbial biomass, whereas $88 \%$ remained in the legume. We found lower $(<0.5 \%)$ ${ }^{15} \mathrm{~N}$ recovery in the microbial biomass (Fig. 2) but up to about $50 \%{ }^{15} \mathrm{~N}$ recovery of fixed ${ }^{15} \mathrm{~N}$ in the soil compartment, which could be due to much shorter labelling period, a dilution of the label in the soil $\mathrm{N}$ pool, or sorption of $\mathrm{N}$ into soil organic matter. 


\section{Accumulation of ${ }^{13} \mathrm{C}$ in Soils and Microbial Biomass}

The accumulation of ${ }^{13} \mathrm{C}$ in the microbial biomass decreased in all vegetation types except in the legume plots, indicating fast microbial turnover of labile compounds into which ${ }^{13} \mathrm{C}$ had been fixed within five weeks. The microbial biomass accounted for a small proportion of the $\mathrm{C}$ pool in our study system, which is in accordance with other studies tracing ${ }^{14} \mathrm{C}$ from $\mathrm{CO}_{2}$ into microbes in tussock and wet sedge tundra $(<2 \%$ of plant assimilated after 7 days of labelling; Loya and others 2002). Very little ${ }^{13} \mathrm{C}$ accumulated in the soils collected in the cyanobacterial crust plots, which is likely a consequence of the low plant abundance, and the lack of roots and root exudates. Yet, microbial ${ }^{13} \mathrm{C}$ as well as ${ }^{15} \mathrm{~N}$ enrichment as fraction of ecosystem recovery was higher in the cyanobacterial crust plots compared to the lichen and moss plots, indicating that the free-living cyanobacteria released $\mathrm{C}$ and $\mathrm{N}$ quickly after fixation and this became available for the microbial pool.

\section{Link Between $\mathrm{N}_{2}$ and C Fixation}

The moss fixed more ${ }^{13} \mathrm{CO}_{2}$ than the other $\mathrm{N}_{2}$ fixers and ecosystem components despite similar or lower $\mathrm{N}_{2}$ fixation. This is probably due to high moss cover and biomass in the plots, compared to the other $\mathrm{N}_{2}$-fixer associations (Table 1). Although the ${ }^{13} \mathrm{C}$ labelling might have increased photosynthesis in the plots (Körner and Diemer 1987), comparisons between the different $\mathrm{N}_{2}$-fixer associations are still valid. The legume and lichen exchange $\mathrm{C}$ for $\mathrm{N}$ with their $\mathrm{N}_{2}$-fixing associates, the more $\mathrm{C}$ the plant fixes, the more $\mathrm{N}$ it might receive in return. Transfer of fixed $\mathrm{N}_{2}$ from moss-associated diazotrophs to the moss has been suggested (Berg and others 2012), but a potential exchange of C remains unknown. However, shortly after fixation, a link between ${ }^{13} \mathrm{C}$ and ${ }^{15} \mathrm{~N}$ enrichment was only found in the lichen and the moss (Fig. 5). Whereas after five weeks of labelling, ${ }^{15} \mathrm{~N}$ and ${ }^{13} \mathrm{C}$ accumulation were linked in the cyanobacterial crust and in the moss. This is in contrast to our second hypothesis, stating that $\mathrm{N}_{2}$ and $\mathrm{C}$ fixation is linked in all $\mathrm{N}_{2}$-fixer associations. The short-term link in the lichen and moss suggests that one process is dependent on the other, or both on each other. The free-living cyanobacteria on the other hand might decouple $\mathrm{N}$ and $\mathrm{C}$ fixation due the damaging effects of C fixation on N fixation (Smith 1984), whereas C fixation in the lichen and moss might be spatially separated from $\mathrm{N}_{2}$ fixation. The link between $\mathrm{N}$ and $\mathrm{C}$ accumulation after five weeks in the moss and cyanobacterial crust might reflect storage of C. For instance, mosses can retain assimilated $\mathrm{C}$ over several weeks, and have been found to allocate $80 \%$ of the C to recalcitrant C pools (Woodin and others 2009, see also Koranda and others 2007; Street and others 2013). Although ${ }^{13} \mathrm{C}$ and ${ }^{15} \mathrm{~N}$ enrichment was not correlated in the legume, $\mathrm{C}$ and $\mathrm{N}$ could still have been taken up simultaneously. The ${ }^{13} \mathrm{C}$ label might be quickly respired, and is diluted by the high amount of $\mathrm{C}$ in the biomass, whereas $\mathrm{N}$ is retained in the legume and other ecosystem compartments. In addition, the symbiotic association between legume and diazotrophs could have had sufficient energy stored to maintain $\mathrm{N}_{2}$ fixation without fixing additional C.

\section{Conclusions}

We have shown that free-living cyanobacteria and particularly legumes represent immediate sources of $\mathrm{N}$ for the ecosystem compared to mosses and lichens, which release $\mathrm{N}$ via slow decomposition and upon disturbances. In $\mathrm{N}$-limited arctic ecosystems, the co-occurrence of different $\mathrm{N}_{2}$ fixers could thus represent a constant supply of 'new' $\mathrm{N}$ for the ecosystem by complementing each other in the timing of $\mathrm{N}$ release. Longer term studies that also include $\mathrm{N}$ sources from decomposition, $\mathrm{N}$ mineralization and nutrient turnover would be highly valuable to inform and parameterize global $\mathrm{N}$ circulation models. Nevertheless, the ecosystem $\mathrm{N}$ cycle might be fundamentally affected in a future climate given the predicted changes in plant communities in the Arctic (for example, shrub expansion at the expense of bryophytes) (Elmendorf and others 2012). Losing the main sources of 'new' $\mathrm{N}$ in $\mathrm{N}$-limited ecosystems however, will have wide ranging implications at ecosystem, if not, at a global level.

\section{ACKNOWLEDGMENTS}

Funding was provided by the Danish Council for Independent Research and FP7 Marie Curie Actions-COFUND (Grant id: DFF-1325-00025, to K.R.). We furthermore gratefully acknowledge financial support from "Docent, Dr. Scient. Lauritz W. Olsons rejsefond" and the Carlsberg Foundation to P.L.S., and from the Danish Council for Independent Research, and the Danish National Research Foundation (Center for Permafrost, CENPERM DNRF100) to A.M. We also thank the Abisko Scientific Station for providing facilities for 
laboratory analyses and fieldwork, Gosha Sylvester for assistance with chemical analyses at the University of Copenhagen, and Signe Lett for valuable comments and suggestions.

\section{OPEN ACCESS}

This article is distributed under the terms of the Creative Commons Attribution 4.0 International License (http://creativecommons.org/licenses/by/ 4.0/), which permits unrestricted use, distribution, and reproduction in any medium, provided you give appropriate credit to the original author(s) and the source, provide a link to the Creative Commons license, and indicate if changes were made.

\section{REFERENCES}

Aldous AR. 2002. Nitrogen retention by Sphagnum mosses: response to atmospheric nitrogen deposition. Can J Bot 80:72131 .

Belnap J. 2001. Factors influencing nitrogen fixation and nitrogen release in biological soil crusts. In: Belnap J, Lange OL, Eds. Biological soil crusts: structure, function, and management. Berlin: Springer. p 241-61.

Berg A, Danielsson $\AA$, Svensson BH. 2012. Transfer of fixed-N from $\mathrm{N}_{2}$-fixing cyanobacteria associated with the moss Sphagnum riparium results in enhanced growth of the moss. Plant Soil 362:271-8.

Carleton TJ, Read DJ. 1991. Ectomycorrhizas and nutrient transfer in conifer-feather moss ecosystems. Can J Bot 69:778-85.

Chapin FSIII, Shaver GR. 1996. Physiological and growth responses of arctic plants to a field experiment simulating climatic change. Ecology 77:822-40.

Cornelissen JHC, Lang SI, Soudzilovskaia NA, During HJ. 2007. Comparative cryptogam ecology: a review of bryophyte and lichen traits that drive biogeochemistry. Ann Bot 99:987-1001.

Crittenden PD. 1998. Nutrient exchange in an Antarctic macrolichen during summer snowfall-snowmelt events. New Phytol 139:697-707.

Dodds WK. 1989. Microscale vertical profiles of $\mathrm{N}_{2}$ fixation, photosynthesis, $\mathrm{O}_{2}$, chlorophyll a and light in a cyanobacterial assemblage. Appl Environ Microbiol 55:882-6.

Dodds WK, Gudder DA, Mollenhauer D. 1995. The ecology of Nostoc. J Phycol 31:2-18.

Elmendorf SC, Henry GHR, Hollister RD, Björk RG, Bjorkman $\mathrm{AD}$, Callaghan TV et al. 2012. Global assessment of experimental climate warming on tundra vegetation: heterogeneity over space and time. Ecol Lett 15:164-75.

Fenton NJ, Bergeron Y, Paré D. 2010. Decomposition rates of bryophytes in managed boreal forests: influence of bryophyte species and forest harvesting. Plant Soil 336:499-508.

Gavazov KS, Soudzilovskaia NA, van Logtestijn RSP, Braster M, Cornelissen JHC. 2010. Isotopic analysis of cyanobacterial nitrogen fixation associated with subarctic lichen and bryophyte species. Plant Soil 333:507-17.

Gundale MJ, DeLuca TH, Nordin A. 2011. Bryophytes attenuate anthropogenic nitrogen inputs in boreal forests. Glob Change Biol 17:2743-53.
Hobara S, McCalley C, Koba K, Giblin AE, Weiss MS, Gettel GM et al. 2006. Nitrogen fixation in surface soils and vegetation in an arctic tundra watershed: a key source of atmospheric nitrogen. Arct Antarct Alp Res 38:363-72.

Hobbie SE. 1996. Temperature and plant species control over litter decomposition in Alaskan tundra. Ecol Monogr 66:50322.

Høgh-Jensen H. 2006. The nitrogen transfer between plants: an important but difficult flux to quantify. Plant Soil 282:1-5.

Houlton BZ, Wang YP, Vitousek PM, Field CB. 2008. A unifying framework for dinitrogen fixation in the terrestrial biosphere. Nature 454:327-31.

Igarashi RY, Seefeldt LC. 2003. Nitrogen fixation: the mechanism of the Mo-dependent nitrogenase. Crit Rev Biochem Mol Biol 38:351-84.

Ininbergs K, Bay G, Rasmussen U, Wardle DA, Nilsson MC. 2011. Composition and diversity of nifH genes of nitrogenfixing cyanobacteria associated with boreal forest feather mosses. New Phytol 192:507-17.

Kallio P, Kallio S. 1978. Adaptation of nitrogen fixation to temperature in the Peltigera aphthosa-group. Ecol Bull 26:225-33.

Knops JMH, Bradley KL, Wedin DA. 2002. Mechanisms of plant species impact on ecosystem nitrogen cycling. Ecol Lett 5:454-66.

Koranda M, Kerschbaum S, Wanek W, Zechmeister H, Richter A. 2007. Physioloigcal responses of bryophytes Thuidium tamariscinum and Hylocomium splendens to increased nitrogen deposition. Ann Bot 99:161-9.

Körner C, Diemer M. 1987. In situ photosynthetic responses to light, temperature and carbon dioxide in herbaceous plants from low and high altitude. Funct Ecol 1:179-94.

Körner C. 2003. Alpine plant life. Functional plant ecology of high mountain ecosystems. 2nd edn. Heidelberg: Springer.

Larmola T, Leppänen SM, Tuittila ES, Aarva M, Merilä P, Fritze $\mathrm{H}$ et al. 2014. Methanotrophy induces nitrogen fixation during peatland development. PNAS 2:734-9.

Larsen KS, Grogan P, Jonasson S, Michelsen A. 2007. Respiration and microbial dynamics in two subarctic ecosystems during winter and spring thaw: effects of increased snow depth. Arct Antarct Alp Res 39:268-76.

Larsen KS, Michelsen A, Jonasson S, Beier C, Grogan P. 2012. Nitrogen uptake during fall, winter and spring differs among plant functional groups in a subarctic heath ecosystem. Ecosystems 15:927-39.

Liengen T, Olsen RA. 1997. Nitrogen fixation by free-living cyanobacteria from different coastal sites in a high arctic tundra, Spitsbergen. Arct Alp Res 29:470-7.

Lindo Z, Nilsson MC, Gundale MJ. 2013. Bryophyte-cyanobacteria associations as regulators of the northern latitude carbon balance in response to global change. Glob Change Biol 19:2022-35.

Longton RE. 1997. The role of bryophytes and lichens in polar ecosystems. In: Woodin SJ, Marquiss M, Eds. Ecology of Arctic environments. Oxford: Blackwell Science. p 69-96.

Loya WM, Johnson LC, Kling GW, King JY, Reeburgh WS, Nadelhoffer KJ. 2002. Pulse labeling studies of carbon cycling in arctic tundra ecosystems: contribution of photosynthates to soil organic matter. Global Biogeochem Cycles 16(4):1101. doi:10.1029/2001GB001464.

Michelsen A, Rinnan R, Jonasson S. 2012. Two decades of experimental manipulations of heaths and forest understory in the subarctic. Ambio 41(Supplement 3):218-30. 
Millbank JW. 1978. The contribution of nitrogen fixing lichens to the nitrogen status of their environment. Environmental role of nitrogen-fixing blue-green algae and asymbiotic bacteria. Ecol Bull 26:260-5.

Mohr RM, Janzen HH, Bremer E, Entz MH. 1998. Fate of symbiotically-fixed ${ }^{15} \mathrm{~N}_{2}$ as influenced by method of alfalfa termination. Soil Biol Biochem 30:1359-67.

Nadelhoffer KJ, Giblin AE, Shaver GR, Linkins AE. 1992. Microbial processes and plant nutrient availability in arctic soils. In: Chapin FSIII, Jefferies RL, Reynolds JF, Shaver GR, Svoboda J, Eds. Arctic ecosystems in a changing climate. An ecophysiological perspective. San Diego: Academic Press. p 281-300.

Oechel WC, Van Cleve K. 1986. The role of bryophytes in nutrient cycling in the taiga. In: Van Cleve K, Chapin FSIII, Flanagan PW, Viereck LA, Dyrness CT, Eds. Forest ecosystems in the alaskan taiga: a synthesis of structure and function. New York: Springer. p 121-37.

Paul EA, Clark FE. 1996. Soil microbiology and biochemistry. London: Academic Press.

Rousk K, Jones DL, DeLuca TH. 2014. Moss-nitrogen input to boreal forest soils: tracking ${ }^{15} \mathrm{~N}$ in a field experiment. Soil Biol Biochem 72:100-4.

Rousk K, Sorensen PL, Lett S, Michelsen A. 2015. Across-habitat comparison of diazotroph activity in the Subarctic. Microb Ecol 69:778-87.

Sistla SA, Schimel JP. 2012. Stoichiometric flexibility as a regulator of carbon and nutrient cycling in terrestrial ecosystems under change. New Phytol 196:68-78.

Smith V. 1984. Effects of abiotic factors on acetylene reduction by cyanobacteria epiphytic on moss at a subantarctic island. Appl Environ Microbiol 48:594-600.
Sorensen PL, Jonasson S, Michelsen A. 2006. Nitrogen fixation, denitrification, and ecosystem nitrogen pools in relation to vegetation development in the subarctic. Arct Antarct Alp Res 38:263-72.

Sorensen PL, Michelsen A, Jonasson S. 2008. Ecosystem partitioning of ${ }^{15} \mathrm{~N}$-glycine after long-term climate and nutrient manipulations, plant clipping and addition of labile carbon in a subarctic heath tundra. Soil Biol Biochem 40:2344-50.

Sorensen PL, Michelsen A. 2011. Long-term warming and litter addition affects nitrogen fixation in a subarctic heath. Glob Change Biol 17:528-37.

Stewart KJ, Coxson D, Siciliano SD. 2011. Small-scale spatial patterns in $\mathrm{N}_{2}$ fixation and nutrient availability in an arctic hummock-hollow ecosystem. Soil Biol Biochem 43:133-40.

Stewart KJ, Grogan P, Coxson DS, Siciliano SD. 2014. Topography as a key factor driving atmospheric nitrogen exchanges in arctic terrestrial ecosystems. Soil Biol Biochem 70:96-112.

Street LE, Subke JA, Sommerkorn M, Sloan V, Ducrotoy H, Phoenix GK, Williams M. 2013. The role of mosses in carbon uptake and partitioning in arctic vegetation. New Phytol 199:163-75.

Van Cleve K, Alexander V. 1981. Nitrogen cycling in tundra and boreal ecosystems. In: Clark FE, Rosswall T, Eds. Terrestrial nitrogen cycles. Ecological bulletins, Vol. 33. Stockholm: Swedish Natural Science Research Council. p 375-404.

Vitousek PM, Field CB. 1999. Ecosystem constraints to symbiotic nitrogen fixers: a simple model and its implications. Biogeochemistry 46:179-202.

Woodin SJ, van der Wal R, Sommerkorn M, Gornall JL. 2009. Differential allocation of carbon in mosses and grasses governs ecosystem sequestration: a ${ }^{13} \mathrm{C}$ tracer study in the high Arctic. New Phytol 184:944-9. 